\title{
STABILITY OF PHILLIPS CURVE: THE CASE OF CROATIA
}

\author{
Zdravko Sergo* $\quad$ Darko Saftic ${ }^{\dagger} \quad$ Ana Tezak $^{\ddagger}$ \\ Keywords: Structural changes, Inflation, Nominal wages, \\ Unemployment, Phillips curve, Croatia \\ JEL: E24
}

\begin{abstract}
Phillips curves are generally estimated under the assumption of linearity and parameter constancy. The conventional Phillips curve argues that there is a trade-off or negative relationship between unemployment and inflation or wage inflation. According to Lucas's critique of econometrics' empirics, however, there is no parameter stability in the forward-looking economic behaviour model of economic agents. Since the rational expectation theory revolution linear models of inflation have been criticised for their poor forecasting performance. Bai and Perron (1998), proposed the methodology which allows for an unknown number of breaks at unknown dates as a response to the mentioned problem. The purpose of this paper
\end{abstract}

*Institute of Agriculture and Tourism Poreč, Department of Tourism, K. Huguesa 8, 52440 Poreč, Croatia, Phone: +385 52408300 Fax: +385 52431 659, E-mail address: zdravko@iptpo.hr

†Institute of Agriculture and Tourism Poreč, Department of Tourism, K. Huguesa 8, 52440 Poreč, Croatia, Phone: +385 52408300 Fax: +385 52431 659, E-mail address: darkos@iptpo.hr

¥Institute of Agriculture and Tourism Poreč, Department of Tourism, K. Huguesa 8, 52440 Poreč, Croatia, Phone: +385 52408300 Fax: +385 52431 659, E-mail address: tezak@iptpo.hr 
is to investigate the linearity and constancy assumptions of the augmented Phillips curve model using expected inflation variables and the methodology proposed by Bai and Perron and to validate the Phillips curve using Croatia as an example. Data used in this analysis was on quarterly basis from 1994 to 2010.

\section{INTRODUCTION}

The empirical studies on the Phillips curve analyzing the relationship of unemployment rates to the inflation rate are the results of the search for a tool for forecasting inflation and implementing monetary policy. The conventional Phillips curve argues that there is a trade-off or negative relationship between unemployment and inflation (Dornbusch, et al., 2005). Started as the result of an empirical investigation of UK wage behaviour by Phillips (1958), it was extended and given a theoretical interpretation by Lipsey (1960), and was applied to the US and set in a policy context by Samuelson and Solow, 1960 P.A. Samuelson and R.M. Solow, Analytical aspects of anti-inflation policy, American Economic Review, Papers and Proceedings 50 (1960), pp. 177-194.Samuelson and Solow (1960), offering policymakers a menu of choice between inflation and unemployment. The original version of the Phillips curve was criticised by Friedman (1968) and Phelps, 1968 E.S. Phelps, Money-wage dynamics and labor-market equilibrium, Journal of Political Economy 76 (1968), pp. 678-711. Full Text via CrossRefPhelps (1968) for not considering the role of inflation expectations. Once these expectations were allowed for, Friedman and Phelps argued that there was no permanent trade-off between inflation and unemployment in the long run, although there could be short run transitory trade-off referred to cyclical fluctuation in economic activity.

Besides, Phillips curves are generally estimated under the assumption of linearity and parameter constancy. But according to Lucas's (1976) critique of econometrics' empirics, there is no parameter stability in the forward-looking economic behaviour model of economic agents. Lucas postulated that changes in the behaviour of policymakers, through their effect on the agents' expecta- 
tions, might cause the estimated parameters from macro-econometric models also to change, so that inferences based on those parameters would be invalid. The above criticism was eventually assumed, so that the original Phillips curve was "augmented" to include expected inflation as an additional variable. The instability of the estimated Phillips curves in the presence of a structural break (following either exogenous shocks or changes in policy regimes) would mean an important obstacle for their use as a policy tool. Hence, the global consensus is in testing the empirics of the augmented Phillips curve to follow a study of structural break or regime shift mechanism.

Relatively recent papers on Phillips curve and its structural break was done by Demers (2003) and Nell (2006). Frédérick Demers (2003) in his paper investigates the linearity and constancy assumptions of a standard reduced-form Phillips curve for Canada using two different techniques: the methodology proposed by Bai and Perron (1998), which allows for an unknown number of breaks at unknown dates, and a three-regimes Markov-switching regression model. Demers in this paper strongly reject the linearity and parameter constancy assumptions. The author finds that the output - inflation relationship does not hold under the current monetary policy of inflation targeting, with its low and stable inflation targeting. Nell (2006) has re-established an important link between inflation and aggregate demand over three decades of data for the South African economy. The main findings, in this paper show that once the Phillips curve model is modified for supply shocks and structural changes in the balanceof-payments and labour market, it accurately predicts South Africa's actual inflation experience from 1971(Q1) until 2001(Q2).

There are a very few number of papers relating to the issue of the Phillips curve and how it applies to Croatian economy. Šergo and Tomčiæ (2003) article investigates the effect of Phillips-Okun's law on the Republic of Croatia in the long run. Družiæ and Tica (2006) are tested hypothesis of relation between unemployment and the rate of change in prices in Croatia with data spanning from 1962 to 2004. Empirical test, in their paper, is designed with a goal of testing the original Phillips curve developed by A. W. Phillips and adaptive expectation augmented Phillips curve designed by Edmund S. Phelps. Authors suggest 
a new theory of accommodation through insolvency for the Croatian economy. Basarac's (2009) paper uses VAR methodology to explore the existence of the so-called New Keynesian Phillips Curve (NKPC) in the case of Croatia. For the purpose of testing the long-term relationship between the key model variables, a co integration analysis was conducted applying Johansen's multivariate procedure. Basarac's paper confirms the long-term existence of co integrating relationship between the core NKPC variables, i.e. inflation, expected inflation and the unit labour cost/output gap. Aljinoviæ, Pivac, and Šego (2009) are tested the interaction between inflation and unemployment by model based on three first-order differential i.e. difference equations: Phillips relation, adaptive expectations equation and monetary-policy equation. The resulting equation, in their paper, was second order differential i.e. difference equation which describes the time path of inflation. They are used monthly data of the rate of inflation in Croatia, from January 1998 to June 2008. On the basis of the estimated time paths, the stability and convergence analysis is done for the rate of inflation in Croatia.

The aim of our paper is to investigate the linearity and constancy assumptions of the augmented Phillips curve model using expected inflation variables. We will use in this paper the methodology proposed by Bai and Perron. On that way we try to validate the Phillips curve using Croatia as an example. Results of this paper contribute to the research program about Phillips curve empirics Croatia's case, in several ways. New econometric technique proposed by Bai and Perron (1998; 2003a; 2003b) was applied in order to test for parameter stability which allows for an unknown number of breaks at unknown dates. Several additional structural break procedures to test the stability of the Phillips curve were applied. These testing were done using Croatia as a case study. Namely, Croatia has experienced low price inflation rates as well as a high unemployment rate, particularly around the year 2002, in the period between the years 1994 and 2010. This tendency is a stylized fact predicted by the original Phillips curve. Therefore a relatively stable Phillips curve relationship in Croatia can a priori be intuited. 


\section{DATA SOURCE AND ANALYSIS}

The data set contains nominal wages, retail consumer price index (RCPI) and the registered unemployment rate in Croatia, from 1994Q2 to 2010Q3. The data was obtained from the Monthly Database on Central, East and Southeast Europe, which can be found on the following website: http://mdb.wiiw.ac.at/. Given that the taken data was at the monthly frequencies level, the data is transformed into a quarter series by means of calculation of a tri-monthly arithmetic mean in a successive way. Wage inflation rate $\Delta$ wt is defined as the log difference (multiplied by 100) of the nominal wages with respect to the previous quarter. Similarly, price inflation rate $\Delta$ pct is the log difference (multiplied by 100) of the retail consumer price index (RCPI).

A historical plot of key macro-economic variables used in this estimation is presented in Figure 1 - 3 .

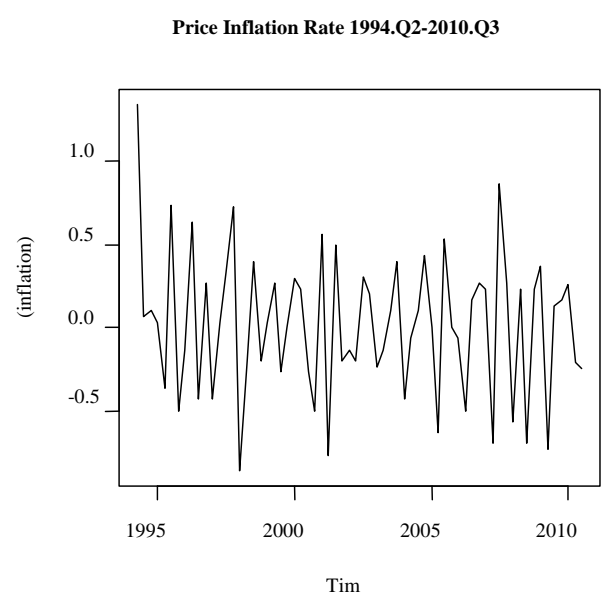

FIGURE 1 Price Inflation Rate 1994Q2 - 2010Q3

Note: x-axis: Time data (1994Q2-2010Q3) in quarterly frequencies

Source: Own calculations 
Economic Research - Ekonomska Istrazivanja Vol. 25, SE 1, 2012 Page:70

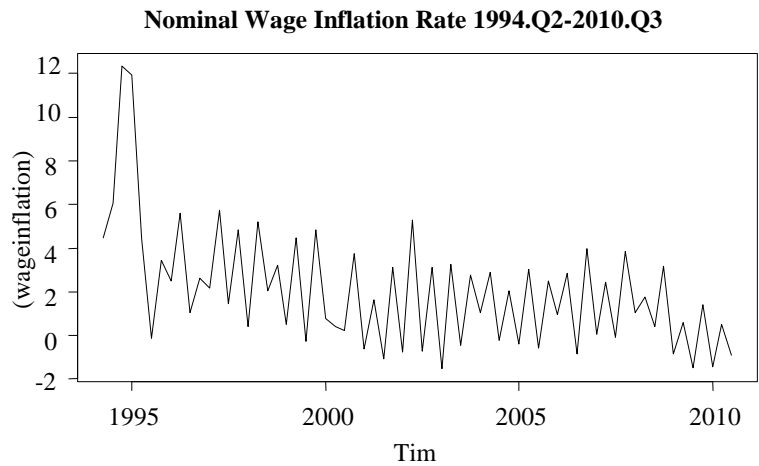

FIGURE 2 Nominal Wage Inflation Rate 1994Q2 - 2010 Q3

Note: x-axis: Time data (1994Q2-2010Q3) in quarterly frequencies

Source: Own calculations

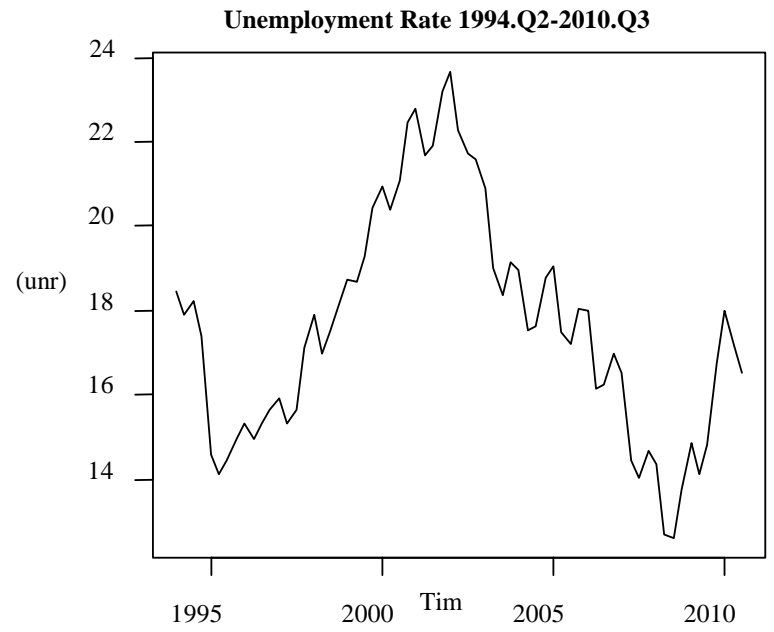

FIGURE 3 Unemployment Rate 1994Q2 - 2010Q3

Note: x-axis: Time data (1994Q2-2010Q2) in quarterly frequencies

Source: Own calculations

Figure 1 shows the inflation rate movement at the quarterly level. It is striking that the inflation rates' quarterly variations almost never surpass the amount 
of $1 \%$, but the amplitudes in movement in this case change fastest. Following the $1.5 \%$ fall in the inflation rate at the beginning of the observation period in 1994 , the inflation oscillated in a relatively narrow variation range of less than $1 \%$ upwards or downwards between the second and the third quarter. Thus the highest degree of volatility of this time series, the proof for it being the highest variation coefficient despite the lowest rate of standard deviation. The greatest contribution to the deceleration of the consumer prices' annual growth in the first two quarters of the year 2010 was provided by the reduction of the annual rates of price changes of processed and unprocessed foodstuff, as well as the services price. Growth of consumer prices inflation, in turn, was caused by the growth of energy prices (petrolium products and gas) and the Croatian kuna (HRK) depreciation against the American dollar (USA \$) (Croatian National Bank Bulletin, 2010).

Figure 2 illustrates the movement of nominal wages' inflation rate. As opposed to the retail price inflation, the nominal wage inflation rate, due to the inherent principle of movement rigidity of real wages downwards, more seldom can be found in the segment of negative growth rates. Following the initial shock of nominal wages growth in the 4th quarter of 1994, which lasts only a short time, until the 1st quarter of 1995, the nominal wage inflation rate falls and then oscillates both in maximal and minimal range, between 12.35 - (-1.54) (see Table 2 ). It is obvious that the syndicate negotiation power stands as the originator of such movements, as the function of syndical action utility is directed to the maintenance of workers' standard of living. Due to this, however, the wages are not flexible downwards, so there is no possibility for the labour market to clear and reduce unemployment. A short episode of extreme growth/fall of nominal wages at the beginning of the story includes the introduction of the Croatian kuna (HRK) following the demolition of inflation in November of 1993, but also a strong government which, during the summer of 1995 recruits a great part of the labour force and, due to a lower labour demand in the 3rd quarter of 1995, nominal wages fall. It is evident that in the movement of nominal wages inflation there is less fluctuation than in the price inflation. The proof for this is a lower variation coefficient in the case of the 1st variable. Non-flexibility 
of wages and the rigidity of the labour supply condition a small probability of disinflational movements when it comes to it. We, notice, however, a rare shock - a shock of nominal wages reduction during the summer of 1995, but also in the last two years. Although due to the use of seasonally unadjusted data this cannot be seen from Figure 2, the salary adjustment by recession conditions in the Croatian economy after the year 2008 is still in progress, so a mild trend of wage reduction can be noticed as from the year 2008 .

At first glance, it appears that there were very strong variations in the quarterly unemployment rates during the long term, however, within a short period, due to characteristic labour market inefficiency and wage rigidity, greater unemployment perseverance during shorter periods occurs. The high unemployment rate perseverance during time dynamics is a well known phenomenon called "hystereses". Thus the variable coefficient, by which we compare the volatility degree between our time series, is the smallest in the case of unemployment. This is reason why the unemployment rate curve does not resemble the earlier growth rate curves, which, in fact, illustrate sinuous movement. For detailed analysis of the labour market in Croatia, see Šergo, Poropat, Gržinić (2009).

The distinction between unit root and stationary processes has become a dominant topic in time-series econometrics and a central issue in empirical macroeconomics. The unit root hypothesis has far-reaching implications with regard both to economic theory and the interpretation of empirical evidence (Culver $\$$ Papel, 1997).

Considerable evidence exists that the nominal wage, and price indexes are $I(1)$ while the unemployment rate is usually $I(0)$. But, those variables are in levels. In specifying an empirical model which we will discuss in the next chapter, we differentiate the equations to ensure stationarity in all the variables. We are going to verify the hypothesis about the absent unit root in our time series.

Table 1 displays the results of the augmented Dickey-Fuller (ADF) test for unit root for the 1994Q2-2010Q2 sample period. We can reject the null hypothesis of the existence of a unit root in the case for the differenced variables. Thus, the price inflation rate and the nominal wage inflation rate are stationary variables $[\mathrm{I}(0)]$. The unemployment rate becomes stationary when the term and trend 
Economic Research - Ekonomska Istrazivanja Vol. 25, SE 1, 2012

Page:73

are constant.

TABLE 1 Unit Root Test

\begin{tabular}{|c|c|c|c|}
\hline & $\begin{array}{c}\text { FIRST } \\
\text { DIFFERENCE OF } \\
\text { LOG(RCPI) }\end{array}$ & $\begin{array}{c}\text { FIRST } \\
\text { DIFFERENCE OF } \\
\text { LOG(Nominal } \\
\text { Wage) }\end{array}$ & $\begin{array}{c}\text { UNEMPLOYMENT } \\
\text { RATE }\end{array}$ \\
\hline & $\mathrm{ADF}$ & ADF & $\mathrm{ADF}$ \\
\hline $\begin{array}{c}\text { Case } \\
1 \\
\text { Case } \\
2 \\
\text { Case } \\
3 \\
\end{array}$ & $\begin{array}{c}-12.535 * \\
(1) \\
-12.588 * \\
(1) \\
-12.697 * \\
(1) \\
\end{array}$ & $\begin{array}{c}-10.683 * \\
(1) \\
-6.741 * \\
(3) \\
-2.141 * \\
(7) \\
\end{array}$ & $\begin{array}{c}-4.102 * \\
(1) \\
-1.769 * \\
(1) \\
-0.403 * \\
(1) \\
\end{array}$ \\
\hline
\end{tabular}

Source: Own calculations

Notes: Case 1 shows that the auxiliary regression is run with a constant and time trend. Case 2 shows that auxiliary regression is run with a constant. Case 3 shows that auxiliary regression is run without any deterministic term.

(*) Implies that the null hypothesis of the existence of a unit root is rejected at a $1 \%$ significance level.

(-) The lag lengths are chosen according to Akaike Information Criteria (AIC) for ADF tests

Zdravko Sergo, Darko Saftic, Ana Tezak - STABILITY OF PHILLIPS

CURVE: THE CASE OF CROATIA 
TABLE 2 Descriptive Statistics

\begin{tabular}{cccc}
\hline \hline & Price Inflation & $\begin{array}{c}\text { Nominal Wage } \\
\text { inflation }\end{array}$ & Unemployment rate \\
\hline Min & -0.86 & -1.543 & 12.6 \\
Max & 1.35 & 12.341 & 23.6 \\
Mean & 0.017 & 2.06 & 17.6 \\
St.dev. & 0.429 & 2.731 & 2.725 \\
Coef.var. & 24.86 & 1.327 & 0.154 \\
\hline \hline
\end{tabular}

Source: Own calculations

\section{MODEL SPECIFICATION}

In his original contribution, Phillips (1958) assumed that the rate of change of nominal wages depended on (a) the unemployment rate, which would be a proxy of excess demand in the labour market; (b) the change in unemployment, which would reflect cyclical factors and (c) the rate of change of retail prices, operating through exogenous shocks, i.e., change in import prices that are large enough to disturb the equilibrium wage/price relationship [see the discussion in Desai, 1984 M. Desai, Wages, prices and unemployment a quarter century after the Phillips curve. In: D.F. Hendry and K.F. Wallis, Editors, Econometrics and quantitative economics, Basil Blackwell, Oxford (1984), pp. 253-273.Desai (1984, 254-255) according to Bajo-Rubio, Díaz-Roldán and Esteve, 2007]. If, in addition, a link between prices and wages is assumed (e.g., prices are set as a markup on wages), the standard Phillips curve equation relating inflation and unemployment would appear.

Formally, the above hypotheses can be stated and tested by regression analysisLayard et al., 1991 R. Layard, S. Nickell and R. Jackman, Unemployment: Macro-economic performance and the labour market, Oxford University Press, Oxford (1991)..

We follow Alogoskoufis and Smith's (1991a) treatment of inflation expectations by agents. Their analysis of the time series behaviour of annual consumer price indexes in Britain and America led them to specify the following relationship: 


$$
\mathrm{E}(\Delta \text { pct } \mid \mathrm{It}-1)=\pi(1-\rho)+\rho \Delta \text { pct- } 1,
$$

where $\pi$ is the anticipated steady-state rate of inflation and $\rho$ is the autoregressive coefficient for price inflation. The inflation expectation term is an exogenous variable in expectations augmented version of Phillips' wage equation. Hence, we consider the following model where we write in a log-linear form,

$$
\Delta \mathrm{wt}=\alpha 0+\alpha 1 \mathrm{E}(\Delta \mathrm{pct} \mid \mathrm{It}-1)-\alpha 2 \Delta \mathrm{ut}-\alpha 3 \mathrm{ut}-1+\xi \mathrm{t},
$$

where $\mathrm{w}$ is the $\log$ of nominal wages, $\mathrm{pc}$ is the log of consumer prices, $\mathrm{u}$ the unemployment rate, and $\xi$ is a white noise error term. The $\alpha$ 's are assumed to be positive/negative parameters according to the regression equation mathematical expectations operator, and I is the information set of wage-setters. Alogoskoufis and Smith (1991) [2] show that the following AR(1) process for rational expectation of price inflation given according to (1) can be substituted as a second regressor in (2). In that way we can get a suitable time series model for a parameter's stability structural change testing:

$$
\Delta \mathrm{wt}=\alpha^{*} 0+\alpha 1 \rho \Delta \mathrm{pct}-1-\alpha 2 \Delta \mathrm{ut}-\alpha 3 \mathrm{ut}-1+\xi \mathrm{t},
$$

where $\alpha^{*} 0=\alpha 0+\alpha 1 \pi(1-\rho)$. Thus we have a system of two equations (1) and (3).

Coefficient $\alpha 3$ represents the responsiveness of the rate of change of wage rates to the lagged unemployment rate and thus characterises wage flexibility. Although nominal wages are present on the left-hand side, the coefficient $\alpha 3$ measures real wage flexibility since price inflation with $\alpha 1$ is present on the right-hand side. The remaining part of nominal wage growth (e.g. due to productivity growth or by more efficient union activity) is captured by the constant term, change in unemployment rate (or economic activity) captured by $\alpha 2$. The error term is assumed to be normal and independently distributed.

\section{METHODOLOGY AND EMPIRICAL RESULTS}

Results of data analysis showed that there is evidence of structural change in our specified model (3), so a natural strategy was to find a model that incorporates the changes. 


\subsection{THE STRUCTURAL CHANGE}

The Bai and Perron procedure allows investigation into whether some or all the parameters of the estimated relationship have changed. More specifically, Bai and Perron, 1998 J. Bai and P. Perron, Estimating and testing linear models with multiple structural changes, Econometrica 66 (1998), pp. 47-78. MathSciNet |Full Text via CrossRef |View Record in Scopus |Cited By in Scopus (577)(Bai and Perron, 1998) and (Bai and Perron, 2003a) consider a linear model with $m$ multiple structural changes (i.e., $m+1$ regimes).

Because the number of breakpoints $m$ is not known in advance, we will compute the optimal breakpoints for $\mathrm{m}=0,1$, . . . breaks and choose the model that minimizes the Bayesian Information Criteria (or BIC as an acronym in proceeding text).

The Bai and Perron tests are based upon an information criterion in the context of a sequential procedure, and allow one to find the number of breaks implied by the data, as well as estimating the timing and the confidence intervals of the breaks, and the parameters of the processes between breaks.

In this paper, we apply the Bai and Perron (1998) test to see whether there are any statistically significant breaks in the specified model (3) and it is this methodology that is repeated here and displayed in Table 4.

So, in terms of structural changes we need to decide how many break points to choose. This is done graphically where the plot of the residual sum of squares (RSS) and the 'BIC' information criterion show that 1 break is appropriate in the case of „BIC“ but not in the case of „RSS “. Although the BIC drops clearly up to $\mathrm{m}=1$ break, the RSS is minimal for $\mathrm{m}=0$ breaks. The structural change tests clearly showed that the model parameters are not stable. Notwithstanding, we proceed with conjecture that there is some evidence of one break date which split the basic regression into two segments. We use the model with $\mathrm{m}=1$ break which occurred very probably at 1999Q2 (see Figure 4). 


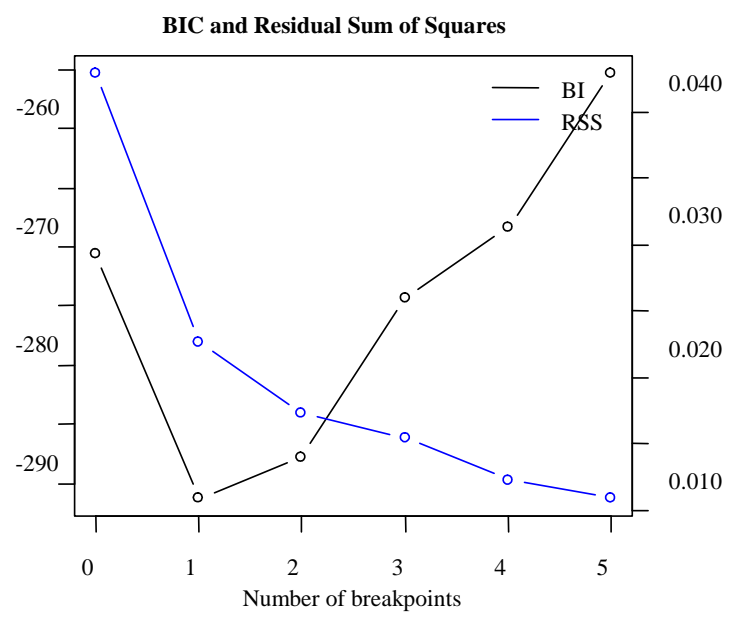

FIGURE 4 The Number of Optimal Breakpoints

Source: Own calculations

The result of the break points estimation is as follows:

TABLE 4 The Break Points Statistics

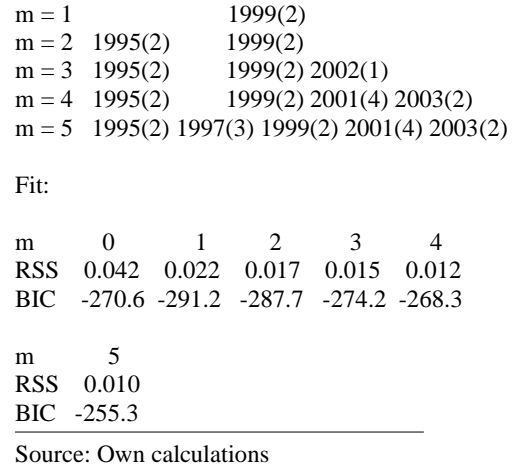

Source: Own calculations

In order to enhance our aforementioned findings that unique break date occurs exclusively in 1999Q2 we have done some additional structural change testing. We included more of the OLS-based CUSUM tests and the test based on F statistics of no structural break in time dynamics. 
The residual-based fluctuation tests or the OLS-based CUSUM test is applied to the model (3) and the result underlines a strong probability that structural shift in our regression exists.

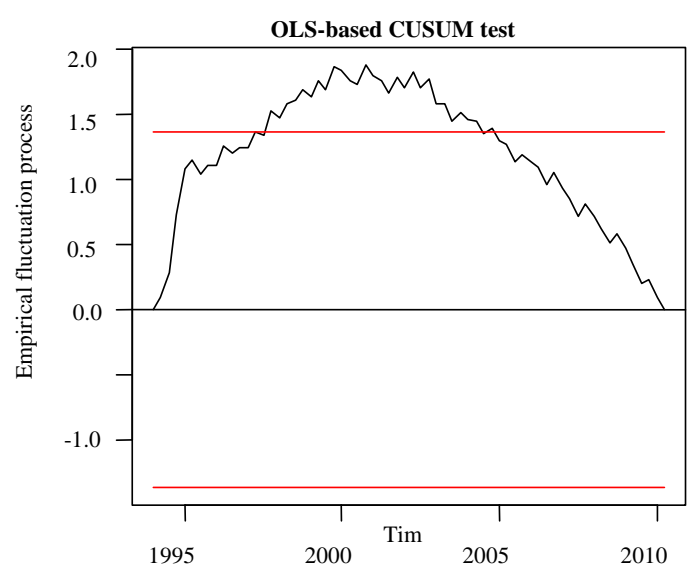

FIGURE 5 OLS-based CUSUM test of no structural break in time dynamics

Note: x-axis: Time data (1994Q2-2010Q2) in quarterly frequencies

Source: Own calculations

Figure 5 shows that CUSUM processes did give evidence of significant fluctuation; thus, that test is able to detect structural changes in the regression model 3. The OLS-based CUSUM structural change test, by default considering the maximum absolute deviation of the empirical fluctuation process from zero and, given that it is significant at the default $5 \%$ level, signals that the model parameters are not stable throughout the entire sample period.

In addition to the excessive fluctuation (conveyed by the boundary crossing), it can be seen from the peak in the process that an abrupt change seems to have taken place in about 1999Q2, matching very well the timing of the first deep recession shock after the post-war recovery in Croatia's economy.

The $\operatorname{SupF}(\mathrm{i}+1 \mid \mathrm{I})$ test is a test for $\mathrm{i}+1$ breaks against the null of $\mathrm{i}$ breaks. The sequential test selects the number of breaks stepwise from zero breaks using 
the SupF test. The break dates are those identified by minimising the sum of squared errors conditional on the number of breaks found.

The resulting process of $F$ statistics is shown in Figure 6, revealing one sharp peak in 1999Q2. Both the boundary crossing and the tiny $\mathrm{p}$ value show that there is significant departure from the null hypothesis F statistics test of structural stability.

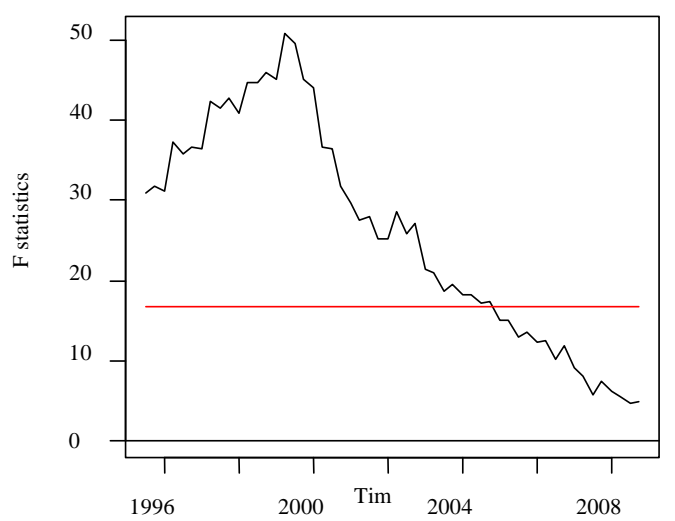

FIGURE 6 SupF test of no structural break in time dynamics Note: x-axis: Time data (1994Q2-2010Q2) in quarterly frequencies

Source: Own calculations

After allowing for one break, the SupF test cannot reject one break in favour of two or two breaks in favour of three at the $1 \%$ significance level.

The sequential test using the results of the SupF test therefore finds one break in the regression model (3) and the OLS - based CUSUM test (see Figure 5) as well as Bai and Perron test selects the most likely date as 1999Q2. Our finding are summarised in Table 5. 
TABLE 5 Review of structural break tests

\begin{tabular}{cccc}
\hline \hline $\begin{array}{c}\text { Type of } \\
\text { Testing }\end{array}$ & $\begin{array}{c}\text { Bai and Perron multiple } \\
\text { structural breaks }\end{array}$ & $\begin{array}{c}\text { OLS-based } \\
\text { CUSUM test }\end{array}$ & $\begin{array}{c}\text { Sequential } \\
\text { test } \\
\text { SupF }(\boldsymbol{i}+\mathbf{1} \mid \boldsymbol{i})\end{array}$ \\
\hline $\begin{array}{c}\text { Critical } \\
\text { statistics }\end{array}$ & $\begin{array}{c}\text { Minimal BIC as } \\
\text { Information criteria }\end{array}$ & $\mathrm{S} 0=1.87 * * *$ & $\begin{array}{c}\mathrm{supF}= \\
50.88 * * *\end{array}$ \\
$\begin{array}{c}\text { No. of } \\
\text { Breaks }\end{array}$ & 1 break & 1 break & 1 break \\
$\begin{array}{c}\text { Breaking } \\
\text { data }\end{array}$ & $1999(2)$ & $1999(2)$ & $1999(2)$ \\
\hline \hline
\end{tabular}

*** represent significance at the $1 \%$ level of significance

Source: Own calculations

\subsection{RESULTS OF REGRESSION ANALYSIS}

The coefficient estimates for the augmented version of Phillips wage curve for Croatia from 1994Q2 ending in 2010Q2 are reported in column A of Table 6. The estimated coefficients have the anticipated signs but only $\alpha 2$ which stands before unemployment first difference is significantly different from zero at the 0.05 probability level. Hence, the change in unemployment rate on a quarterly basis, which reflects short-run cyclical factors, is linked to nominal wage change. If the lagged economic activity increases in terms of decreasing unemployment rates, then inflation of nominal wages occur.

The coefficients for two time segmented regression with related statistics are given in Table 6 as column $\mathrm{B}$ and $\mathrm{C}$ respectively. The difference in all coefficients and particularly signs before price inflation change in two regressions reflecting that the period after the first half of 1999 (by the way this was the first recession year till 2009 in Croatia's economy) is different from the previous observations. The result of the regression $\mathrm{B}$, which covers the period between 1994Q2 and 1999Q2 increases the statistical significance of the difference of the null hypothesis which measures the difference of the lagged unemployment rate. On the other hand, no parameter of the regression $\mathrm{C}$, which covers the period between 1999Q3 and 2010Q2, is no longer significant and a very low coefficient 
of determination $\boldsymbol{R}^{2}$, which provides a measure of how well future outcomes of nominal wage change are likely to be predicted by the anticipated model, offers very little hope in relation to the model representative quality. The coefficient which measures real wage flexibility in regard to lagged unemployment rate has in the second regression B a wrong sign. The highest t-value which measures significance in regard to real wage flexibility to the change of lagged economic activity is reached in the second period. However, as a conclusion, the thesis that the estimated parameters according to the regression $\mathrm{C}$ do not provide a statistically convincing framework of undertaking of adequate economic politics measures for prevention of increasing unemployment in the Republic of Croatia. This brief pessimistic abstract is all the more pessimistic since it is a result of implementation of segmentary regressions which were a fruit of rigorous testing of the dynamics of structural breaks.

TABLE 6 Expectations Augmented Wage Inflation Regression

\begin{tabular}{|c|c|c|c|}
\hline Variables & $\begin{array}{c}\text { (A) } \\
\text { 1994Q2-2010Q2 }\end{array}$ & $\begin{array}{c}(B) \\
\text { 1994Q2-1999Q2 }\end{array}$ & $\begin{array}{c}(C) \\
1999 Q 3-2010 Q 2 \\
\end{array}$ \\
\hline Constant & $\begin{array}{c}0.04412 \\
(1.994)\end{array}$ & $\begin{array}{c}0.046 \\
(0.792)\end{array}$ & $\begin{array}{c}0.008 \\
(0.482)\end{array}$ \\
\hline$\Delta$ pct- 1 & $\begin{array}{c}0.34533 \\
(0.410)\end{array}$ & $\begin{array}{l}-1.620 \\
(-1.306)\end{array}$ & $\begin{array}{c}1.266 \\
(1.735)\end{array}$ \\
\hline$\Delta \mathrm{ut}$ & $\begin{array}{l}-0.68045 \\
(-1.879)\end{array}$ & $\begin{array}{c}-2.760 \\
(-4.226) * * *\end{array}$ & $\begin{array}{c}-0.078 \\
(-0.269)\end{array}$ \\
\hline ut- 1 & $\begin{array}{l}-0.13179 \\
(-1.062)\end{array}$ & $\begin{array}{l}-0.036 \\
(-0.102)\end{array}$ & $\begin{array}{l}0.0191 \\
(0.201)\end{array}$ \\
\hline$R 2$ & 0.15 & 0.57 & 0.08 \\
\hline RSE & 0.026 & 0.02 & 0.02 \\
\hline DW & 1.73 & 1.93 & 3.19 \\
\hline
\end{tabular}

Source: Own calculations

\section{CONCLUSION}

The objective of this paper was to explain the stability of the expectations 
of the augmented Phillips curve relationship between unemployment and wage inflation in Croatia.

Following Lucas' destructive criticism about the inability of the Phillips curve deep parameters to maintain stability due to continuous shocks from the complex macro-environment and rational adjustments of agents, thus the uselessness of the econometric exercise, which might result in macro-economic management in the selection of the combination of a desired inflation rate and unemployment rate, the researches of the Phillips curve problem are focused on examination of structural breaks in regression.

An exchange-rate peg is a very dangerous strategy for controlling inflation in Croatia in the long run, there is no doubt. Same economic experts in Croatia advocate that the monetary politics should allow depreciation of Croatian kuna exchange rate $(\mathrm{HRK})$. Instead of pegging the kuna exchange rate against value of euro (with very narrow up and down deviations), the Croatia's Central Bank should introduce inflation targeting (for broader information, see: weekly news Globus, No. 1043, 12/3/2010). The moderate inflation rate as a legitimate economic aim could spill benefits in fighting against high unemployment rate. Consequently, this would result in mild inflation targeting growth around $10 \%$ at annually basis and would be a beneficial remedy for unemployment reduction. Our paper demonstrated that the causes of unemployment in Croatia occurred due to structural reasons, and not due to low inflation rate. The anti-inflation shock from November 1993 and the price stability obtained after that might have initiated the causes of very high and permanent unemployment rate. But, the Phillips curve, analysed in this paper, today is no longer valid. Thus, inflation targeting as a monetary policy goal, in the light of our research, is questionable macro-management.

Conducting a multiple testing of the hypotheses on possible breaks in the basic regression equation during the second quarter of the year 1999 and (this was a recession year and the fall of real GDP equalled approximately 1.98\%), had no effect on the parameter significance tests because they were not sufficiently high in order to reject the null hypothesis of some parameters in the third segmentary regression (it encompasses the period of between 1999Q3 and 2010Q2). 
Although the negative trade-off between the changes in unemployment rate, which reflect short-run cyclical factors and a nominal wage change had existed prior, it seems that such an important stylised fact relationship was lost after 1999Q2.

\section{REFERENCES}

Aljinović, Z.; Pivac, S.; Šego, B. (2009): An Expectation of the Rate of Inflation According to Inflation-Unemployment Interaction in Croatia, International Journal of Business, Economics, Finance and Management Sciences, Vol. 1, No.1, pp.1-5.

Alogoskoufis, G.S.; Smith, R. (1991): The Phillips Curve, The Persistence of Inflation, and the Lucas Critique: Evidence from Exchange-Rate Regimes, American Economic Review, Vol. 81, No. 5, pp.1254-1275.

Bai J. (1994): Least Squares Estimation of a Shift in Linear Processes, Journal of Time Series Analysis, Vol. 15, pp. 453-472.

Bai J. (1997): Estimation of a Change Point in Multiple Regression Models, Review of Economics and Statistics, Vol. 79, pp. 551-563.

Bai J.; Perron P. (1998): Estimating and Testing Linear Models with Multiple Structural Changes, Econometrica, Vol. 66, pp. 47-78.

Bai, J.; Perron, P. (2003): Computation and analysis of multiple structural change models, Journal of Applied Econometrics, Vol. 18, No. 1, pp. 1-22.

Bai, J.; Perron, P. (2003): Critical values for multiple structural change tests, Econometrics Journal, Vol. 6, No. 1, pp. 72-78.

Bajo-Rubio, O.; Díaz-Roldán, C.; Esteve, V. (2007): Change of regime and Phillips curve stability:The case of Spain, 1964-2002, Journal of Policy Modeling, Vol. 29, Is. 3, pp. 453-462.

Basarac, M. (2009): New Keynesian Phillips Curve Applied to the Case of Croatia: The VEC Model, Economic Trends and Economic Policy, Vol.119, pp. $27-52$. 
Economic Research - Ekonomska Istrazivanja Vol. 25, SE 1, 2012

Croatian National Bank (2010): Banks Bulletin No. 162: Press Releases, 8 September 2010, http://www.hnb.hr/publikac/bilten/arhiv/bilten162/ebilt162.pdf, (accessed 13 October 2010)

Culver, S.E.; Papell, D.H. (1997): Is there a unit root in the inflation rate? Evidence from sequential break and panel data models, Journal of Applied Econometrics, Volume 12, Issue 4, pp. 35-444.

Demers, F. (2003): The Canadian Phillips Curve and Regime Shifting, Working Papers 03-32, Bank of Canada, http://www.bankofcanada.ca/en/res/ wp/2003/wp03-32.pdf, (accessed 18 October 2010)

Desai, M. (1984): Wages, prices and unemployment a quarter century after the Phillips curve, in: Hendry, D.F. and Wallis, K.F., ed.: Econometrics and quantitative economics, Basil Blackwell, Oxford, pp. 253-273

Dornbusch, R.; Fisher, S.; Startz, R. (2005): Macroeconomics, Ninth Edition, McGraw-Hill Education, New York

Družić, I.; Tica, J.; Mamiæ, A. (2006): The Challenge of Application of Phillips Curve: The Case of Croatia, Zagreb International Review of Economics and Business, Vol. 9, pp. 45-60.

Friedman, M. (1968): The Role of Monetary Policy, American Economic Review, Vol. 58, No. 1, pp. 1-17.

Jelić, N. (2010): Tihi ustanak protiv Rohatinskog: 8 teza, 8 ekonomista za novi HNB, Globus, November, No. 1043, http://globus.jutarnji.hr/hrvatska/tihiustanak-protiv-rohatinskog, (accessed 02 December 2010)

Lucas, R.E. (1976): Econometric Policy Evaluation: A Critique, in Brunner, K. and Meltzer A.H., ed.: The Phillips Curve and Labor Markets: Carnegie-Rochester Conference Series on Public Policy: Vol. 1, North-Holland, Amsterdam, pp. 19-46

Nell, K.S. (2006): Structural Change and Nonlinearities in a Phillips Curve Model for South Africa, Contemporary Economic Policy, Vol. 24, No. 4, pp. 600-617.

Phelps, E. S. (1968): Money-Wage Dynamics and Labor-Market Equilibrium, Journal of Political Economy, Vol. 76, No. 4, pp. 678-711. 
Economic Research - Ekonomska Istrazivanja Vol. 25, SE 1, 2012

Page: 85

Phillips, A. W. (1958): The Relation between Unemployment and the Rate of Change of Money Wage Rates in the United Kingdom, 18611957, Economica, Vol. 25, No. 100, pp. 283-299.

Samuelson, P. A.; Solow, R. M. (1960): Analytical Aspects of Anti-Inflation Policy, American Economic Review, Vol. 50, No. 2, pp.177-194.

Šrgo, Z.; Tomčiæ, Z. (2003): Testing the Phillips-Okun Law and Growth Irregularity: the Case of Croatia, in: Fifth International Conference: Enterprise in Transition, Proceedings, Faculty of Economics Split, May 22-24, 2003, pp. 69-110

Šergo, Z.; Poropat, A.; Gržiniæ, J. (2009): Croatia’s Beveridge Curve And Estimation Of Natural Rate Of Unemployment: 1990-2008, Economic Research, Vol. 22 No. 3, pp. 29 - 47.

The Wienna Institute For International Economic Studies (2010): Monthly Database on Central, East and Southeast Europe, http://mdb.wiiw.ac.at, (accessed 15 October 2010) 